J. Clin. Chem. Clin. Biochem.

Vol. 23, 1985, pp. $63-68$

\title{
Enzyme Linked Immunosorbent Assay for Human Apolipoprotein C-III
}

\author{
By J. Bury and Maryvonne Rosseneu \\ Department of Clinical Chemistry A.Z. St. Jan, Brugge, Belgium
}

(Received July 9/September 21, 1984)

Summary: A sandwich enzyme linked immunosorbent assay (ELISA) for apolipoprotein C-III was developed. Anti apolipoprotein C-III immunoglobulins were used both for coating of microtitre plates and for the preparation of an anti apolipoprotein C-III horse-radish peroxidase conjugate.

Under optimized assay conditions, the sensitivity lies around $0.3 \mathrm{ng}$ apolipoprotein C-III with a working range of 1 to $6 \mathrm{ng}$. Standard curves are parallel for purified apolipoprotein C-III, for untreated plasma and for lipoprotein fractions. Delipidation did not affect the content of apolipoprotein C-III in plasma. The assay was evaluated by comparison with an immunonephelometric assay for apolipoprotein $\mathrm{C}$-III, yielding a correlation coefficient of $0.982(n=79)$. The mean intra- and interassay CV for the whole working range of the assay were $3.6 \%$ and $4.2 \%$ respectively.

\section{Enzyme linked immunosorbent assay (ELISA) für menschliches Apolipoprotein C-III}

Zusammenfassung: Ein sandwich enzyme linked immunosorbent assay (ELISA) für Apolipoprotein C-III wurde entwickelt. Für die Beschichtung von Mikrotiterplatten sowie die Herstellung eines anti-Apoliprotein C-III-Meerrettichperoxidase-Konjugats wurden anti-Apolipoprotein C-III-Immunglobuline benutzt.

Unter optimierten Bedingungen beträgt die Empfindlichkeit des Bestimmungsverfahrens etwa 0,3 ng Apolipoprotein C-III bei einem Einsatzbereich von 1-6 ng. Die Standardkurven für gereinigtes Apolipoprotein CIII, unbehandeltes Plasma und Lipoproteinfraktionen verlaufen parallel. Die Lipidabtrennung beeinflußte den Gehalt von Apolipoprotein C-III im Plasma nicht. Das Bestimmungsverfahren wurde durch Vergleich mit einer immunnephelometrischen Methode zur Bestimmung von Apolipoprotein C-III geprüft; der Korrelationskoeffizient betrug $0,982(n=79)$. Die mittleren Variationskoeffizienten betrugen innerhalb der Serie 3,6\% und von Tag zu Tag 4,2\%.

\section{Introduction}

Until recently, the investigation of various types of dyslipoproteinaemia was mainly confined to the measurement of the plasma lipid concentrations. A better understanding of the major physiological functions of the apolipoproteins has stressed the importance of their quantification in plasma $(1,2)$. Most studies have focused on the major apolipoproteins of HDL (apolipoproteins A-I and A-II) and LDL (apolipoprotein B).
The C- and E apolipoproteins play an important role in lipoprotein metabolism. Apolipoprotein CIII, being a major constituent of triglyceride-rich lipoproteins and a minor constituent of HDL, is known as an inhibitor of lipoprotein lipase in vitro $(3,4)$ and might also prevent the hepatic uptake of triglyceride-rich lipoproteins $(5,6)$.

Immunological assays have been developed mainly for the apolipoproteins A-I, A-II and B proteins by a variety of techniques $(7,8)$. Quantitation of 
apolipoprotein C-III by radioimmunoassay (RIA) $(9$, 10). electroimmunodiffusion (EID) (11), a competitive enzyme linked immunosorbent assay (ELISA) (12) and an immunonephelometric assay (INA) (13) have been previously reported.

This report describes the technical optimization and the validation of a sandwich enzyme linked immunosorbent assay (ELISA), which was developed for the measurement of human apolipoprotein C-III in plasma and in lipoprotein fractions. Results are evaluated by comparison with other techniques, described previously.

\section{Material and Methods}

\section{Isolation of apoliprotcins and production of antisera}

The three apolipoprotein C-III isoforms (i.e. apolipoproteins $\mathrm{C}-\mathrm{III}_{0}, \mathrm{C}-\mathrm{III}_{1}$ and $\left.\mathrm{C}-\mathrm{III}_{2}\right)$ were isolated from human apolipoprolcins of Very Low Density Lipoproteins by a combination of gel filtration on a Sephacryl S 200 column and ionexchange chromatography on a DEAE-cellulose column, as described previously (13). The homogeneity of the apolipoprotein C-III preparation, used as primary standard and immunogen, was checked by clectrophoresis on polyacrylamide gcls, containing cither $8 \mathrm{~mol} / \mathrm{l}$ urca (14) or $1 \mathrm{~g} / \mathrm{l}$ sodium dodecyl sulphate (15), by immunodiffusion with antisera against apolipoprotein A-I, A-II, B, C-III, E and albumin, and by amino acid analysis, based on the composition of purified apolipoprotein C-III (16).

Apolipoprotein A-I and apolipoprotein A-II were purified from apo High Density Lipoproteins by ion exchange chromatography $(17,18)$. Watcr soluble apolipoprotein B was prepared from Low Density Lipoproteins $(\mathrm{d}=1.030-1.050 \mathrm{~kg} / \mathrm{l})$ as described by Cardin et al. (19) and apolipoprotein E were isolated from apolipoproteins of Very Low Density Lipoproteins by high performance liquid chromatography using an UltroPak TSK-G 3000 SW column (LKB, Broma, Sweden) $(20,21)$.

The antiscra to these purified apolipoproteins were raised in rabbits as prcviously described $(13,18,22,23)$.

\section{Preparation of the coater and the enzyme-antibody conjugate}

An apolipoprotein C-III affinity column was prepared by covalent linkage of $8 \mathrm{mg}$ apolipoprotein C-III to $1 \mathrm{~g} \mathrm{CNBr}$ activated Sepharosc 4 B (Pharmacia, Uppsala, Sweden) (24). Anti human apolipoprotein C-III immunoglobulins were isolated from a rabbit antiserum by affinity chromatography, according to the standard procedure, and were used both for coating and for the preparation of an enzyme-antibody conjugate. For this purpose $2 \mathrm{mg}$ of horse-radish peroxidase was covalently linked to $4 \mathrm{mg}$ purified anti-apolipoprotein C-III immunoglobulin by the periodate coupling procedure described by Nakane (25).

The immunoglobulins, used for coating, wcre stored at $4^{\circ} \mathrm{C}$ in $0.05 \mathrm{~mol} / \mathrm{l}$ sodium borate, $0.15 \mathrm{~mol} / 1 \mathrm{NaCl}$, containing $1 \mathrm{~g} / \mathrm{l}$ $\mathrm{NaN}_{3}$, while the antibody-enzyme conjugate was stored in aliquots at $-20^{\circ} \mathrm{C}$, mixed with an equal volume of glycerol (26). This preparation was stable for at least six months, without any loss of activity.

\section{Buffer system}

A sodium phosphate buffer $10 \mathrm{mmol} / 1 \mathrm{pH} \mathrm{7.4,} \mathrm{containing}$ $0.15 \mathrm{~mol} / \mathrm{l} \mathrm{NaCl}$ was used throughout the whole procedure for coating, incubations and washings. In addition the coating buffer contained $1 \mathrm{~g} / 1 \mathrm{NaN}_{3}$, whereas the assay buffer contained $10 \mathrm{~g} / \mathrm{l}$ bovine serum albumin (27). To reduce non-specific binding, the wash buffer contained $0.5 \mathrm{ml} / \mathrm{l}$ Tween 20 (26).

\section{Coating of the solid phase}

Purified anti-apolipoprotein C-III immunoglobulins (110 $\mu$ ) at a concentration of $25 \mathrm{mg} / \mathrm{l}$ were pipetted'into each well of a polystyrene microtitre plate (Flat Bottom micro ELISA plates, 129 B, Dynatech Lab Inc., Alexandria, Virginia, 22314), excluding the outer rows which tend to produce edge effects (28). The plates were sealed (Sealing tape, Dynatech), and incubated for $3 \mathrm{~h}$ at $37^{\circ} \mathrm{C}$ before an overnight incubation at $4^{\circ} \mathrm{C}$. The plates were used either immediately or stored with the coater at $4^{\circ} \mathrm{C}$ for a maximum of two weeks. Before use the plates were washed three times with wash buffer and incubated one hour at room temperature with the assay buffer, in order to block any residual coupling sites with albumin (29). The plates were subsequently washed three times and shaken dry.

\section{Apolipoprotein C-III quantitation by sandwich ELISA}

Standard or plasma samples $(100 \mu l)$, representing 5000 -fold dilutions (Microlab 1000 dilutor, Hamilton, Bonaduz, Switzerland), were pipetted into the wells of a precoated microtitre plate. The plates were covered and incubated at $37^{\circ} \mathrm{C}$ for $2 \mathrm{~h}$. The content of each well was aspirated and the plates were washed five times. After 10000 dilution with assay buffer, the affinity purified anti-apolipoprotein C-III peroxidase conjugate $(100 \mu \mathrm{l})$ was added to each well and plates were incubated for $2 \mathrm{~h}$ at $37^{\circ} \mathrm{C}$. The wells were subsequently emptied and washed five times. The $o$-phenylenediamine hydrochloride substrate (Sigma chemical Co, St. Louis, MO 63178), at a concentration of $3 \mathrm{~g} / \mathrm{l}$, was freshly prepared in a $0.01 \mathrm{~mol} / 1$ sodium-phosphatecitrate buffer pH 5.6, containing $0.2 \mathrm{~g} / 1 \mathrm{H}_{2} \mathrm{O}_{2}$. An aliquot of this solution $(100 \mu \mathrm{l})$ was pipetted into each well at timed intervals and left at room temperature in the dark. After $30 \mathrm{~min}$ the reaction was blocked by adding $100 \mu \mathrm{l}$ of $2.5 \mathrm{~mol} / \mathrm{l}$ sulphuric acid (Analytical Grade, Merck, Darmstadt, FRG). The developed colour was read within two hours on a Chromo Scan EIA Reader (Bio-Tech Instrument, Burlington, VT 05401) at $490 \mathrm{~nm}$.

Calibration curves were obtained from the appropriate dilutions of purified apolipoprotein $\mathrm{C}-\mathrm{III}_{2}$, whose concentration was assessed by amino acid analysis. This primary standard was solubilized in the sodium phosphate buffer, containing the nonionic detergent Apovax (Ortho Diagnostics, Beerse, Belgium) at a concentration of $0.1 \mathrm{~g} / \mathrm{l}$, then further diluted with the ELISA assay-buffer. Sera from normolipidaemic donors, aliquoted and stored at $-20^{\circ} \mathrm{C}$, were used as a suitable secondary standard and control $(7,8)$. Standard curves were obtained by plotting the absorbance at $490 \mathrm{~nm}$ as function of the logarithm of the apolipoprotein C-III concentration.

\section{Apolipoprotein C-III distribution in lipoprotein fractions}

Lipoproteins were separated from $1 \mathrm{ml}$ fresh disodium EDTAplasma $(1 \mathrm{~g} / \mathrm{l})$ by gel filtration on a Sepharose $6 \mathrm{BCL}$ column $(1.6 \times 90 \mathrm{~cm})$, equilibrated with $2 \mathrm{mmol} / 1 \mathrm{Na}_{3} \mathrm{PO}_{4}, 0.2 \mathrm{~mol} / \mathrm{l}$ $\mathrm{NaCl}, 1 \mathrm{mmol} / 1$ disodium EDTA and $1 \mathrm{~g} / 1 \mathrm{NaN}_{3}, \mathrm{pH} 7.4$ and eluted at $9.2 \mathrm{ml} / \mathrm{h}$. Apolipoprotein C-III was assayed in all fractions by the ELISA procedure described above and cholesterol was assayed enzymatically $(30)$.

\section{Results}

Optimization of the assay conditions

Optimal coating concentration and conjugate dilution were determined by using the chequerboard titration, 
described by Voller et al. (26). A good sensitivity, together with a low zero-dose response were achieved, using a coating concentration of $25 \mu \mathrm{g}$ purified antiapolipoprotein C-III immunoglobulins per ml coating buffer and a final antibody-peroxidase dilution of 10000 fold.

A second coating with albumin, to block any residual binding sites on the polystyrene plates (29) decreased the intra-assay $\mathrm{CV}$ by a factor two. This procedure, in combination with the use of $0.5 \mathrm{ml}$ Tween 20 per 1 wash buffer, yielded a four-fold increase of the intraassay precision from $13.5 \%$ to $3.8 \%$.

\section{Standardization}

As shown in figure 1, the calibration curve constructed with purified apolipoprotein $\mathrm{C}-\mathrm{III}_{2}$ and with the plasma obtained from a normolipidaemic subject and from a subject with a severe Fredrickson type V hyperlipoproteinaemia (triglycerides $47.25 \mathrm{~g} / 1$ and cholesterol $8.85 \mathrm{~g} / \mathrm{l}$ ) were identical. Delipidation of the plasma samples (31) did not increase the apolipoprotein C-III immunoreactivity, indicating that all apolipoprotein C-III epitopes are accessible to titration in native plasma.

The calibration curves, obtained with lipoprotein fractions freshly isolated from plasma by sequential ultracentrifugation, paralleled the standard curve constructed with purified apolipoprotein $\mathrm{C}-\mathrm{III}_{2}$ (fig. 2). Identical curves were obtained after delipidation of chylomicra, Very Low Density Lipoproteins and High Density Lipoproteins.

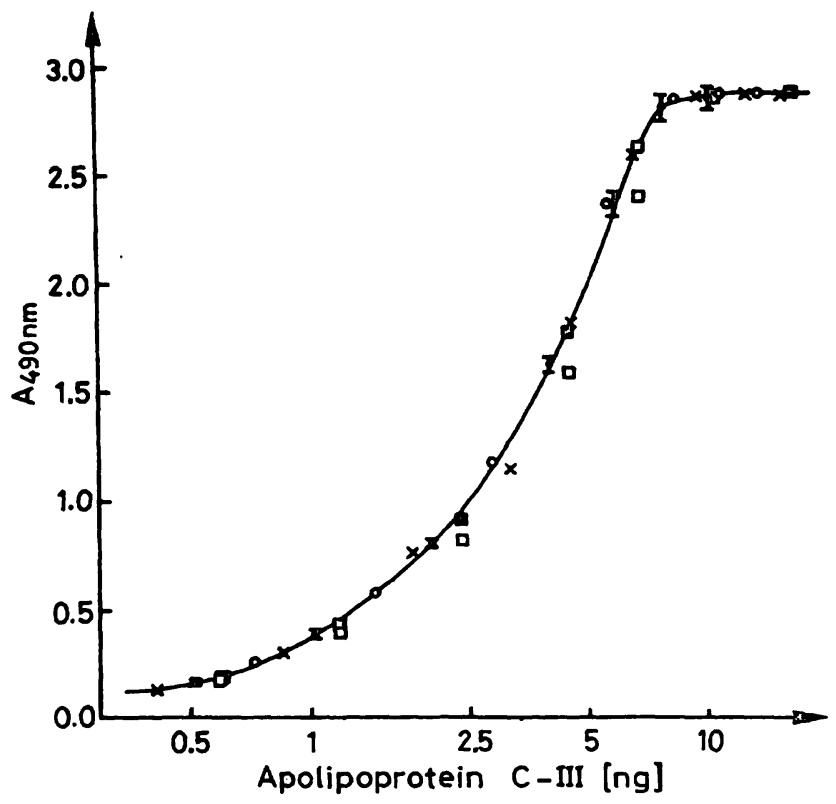

Fig. 1. Calibration curves for apolipoprotein C-III quantitation by ELISA: purified apolipoprotein $(x)$, normolipidaemic plasma (\$) (mean \pm 1 SD), normolipaemic delipidated plasma $(O)$, plasma from a Fredrickson type V patient native ( $(\mathbb{})$ and delipidated (ㅁ).

\section{Sensitivity, precision and accuracy}

The enzyme linked immunosorbent assay is sensitive down to $0.3 \mathrm{ng}$ apolipoprotein C-III with a working range of 1 to $6 \mathrm{ng}$ apolipoprotein C-III. Using a 5000 fold dilution, this range corresponds to apolipoprotein C-III plasma concentrations between 0.05 and 0.30 $\mathrm{g} / \mathrm{l}$.

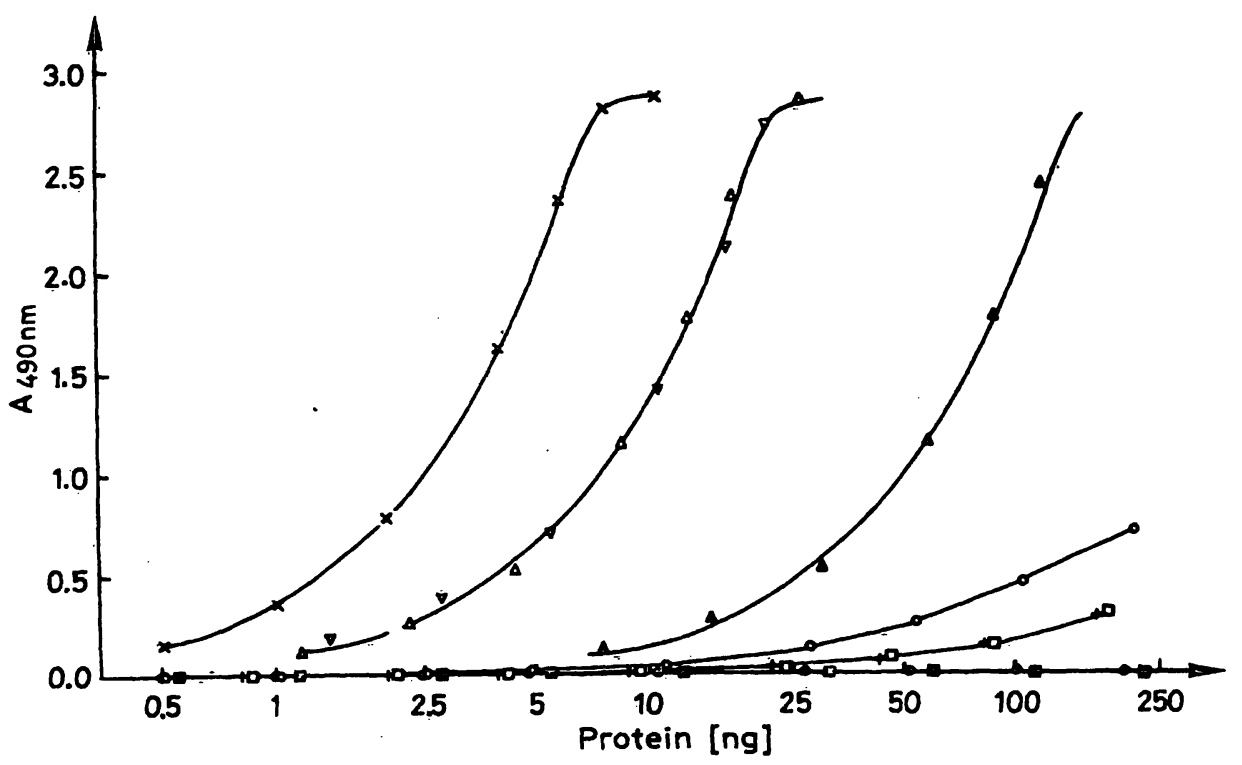

Fig. 2. Standard curves, constructed with purified apolipoprotein C-III $(x)$, chylomicra $(\triangle)$, VLDL $(\nabla)$ and $\mathrm{HDL}_{2}(\Delta)$, apolipoproteins A-I (O), A-II (Q), B ( $\square), E(+)$ and human albumin (四). 
The selectivity of the ELISA for apolipoprotein CIII was investigated by constructing calibration curves with purified apolipoproteins A-I, A-II, B, C- $\mathrm{III}_{2}, \mathrm{E}$ and human albumin. As shown in figure 2, the crossreactivity of these antigens with anti-apolipoprotein C-III immunoglobulins, amounted to $1.02,0.00,0.51$, $100.00,0.56$ and $0.00 \%$ respectively.

Five plasma samples, with low, intermediate and high concentrations of apolipoprotein C-III, were analysed twenty times in the same assay and twice a week during five weeks to calculate the assay precision. As shown in table 1 , the average intra- and inter-assay CV amounted to $3.6 \%$ and $4.2 \%$ respectively.

Tab.1. Precision of the apolipoprotein C-III ELISA assay.

\begin{tabular}{lll}
\hline $\begin{array}{l}\text { Apolipoprotein C-III } \\
\text { concentration } \\
(\mathrm{g} / \mathrm{l})\end{array}$ & $\begin{array}{l}\text { Intra-assay CV } \\
(\mathrm{n}=20) \\
(\%)\end{array}$ & $\begin{array}{l}\text { Inter-assay CV } \\
(\mathrm{n}=10) \\
(\%)\end{array}$ \\
\hline 0.090 & 4.33 & 2.84 \\
0.126 & 4.14 & 2.39 \\
0.144 & 3.83 & 4.87 \\
0.220 & 3.81 & 5.67 \\
0.303 & 1.86 & 5.36 \\
\hline
\end{tabular}

In order to investigate the accuracy of the assay, apolipoprotein C-III was assayed in 79 plasma samples both by immunonephelometry (13) and by the ELISA procedure described above. The regression line between the two techniques (fig. 3) has a correlation coefficient of 0.982 and is represented by the equation $y=0.988 \mathrm{x}-0.002$. A paired $\mathrm{t}$-test failed to detect any significant difference $(p<0.05)$ between the two immunoassays.

\section{Apolipoprotein C-III concentrations in human plasma}

Table 2 summarizes the plasma concentrations of apolipoprotein C-III in normal and hyperlipoproteinaemic subjects as determined by the ELISA procedure. The mean apolipoprotein C-III concentration in 34 normolipaemic subjects was $0.101 \pm$ $0.03 \mathrm{~g} / \mathrm{l}$. Fredrickson type II a patients had only slightly

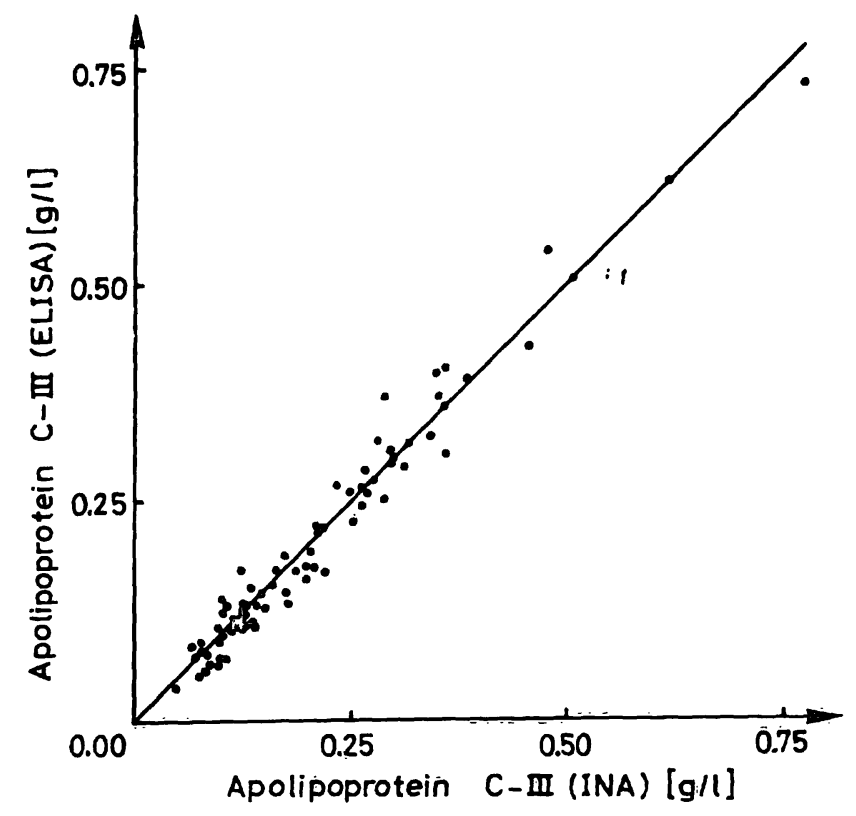

Fig. 3. Correlation between the enzyme linked immunosororbent assay (ELISA) and the immunonephelometric assay (INA) for the quantitation of plasma apolipoprotein CIII.

$y=0.988 x-0.002 . \quad r=0.982 . \quad N=79$

elevated apolipoprotein C-III levels, whereas all other hyperlipoproteinaemic subjects had significantly higher $(p<0.001)$ apolipoprotein C-III values than normals and type II a patients. The highest apolipoprotein C-III concentrations were observed in Fredrickson type $\mathrm{V}$ hyperlipoproteinaemic patients.

Investigations on 76 patients with a wide range of total plasma triglycerides $(0.27-47.25 \mathrm{~g} / \mathrm{l})$, and total plasma cholesterol $(1.02-8.85 \mathrm{~g} / \mathrm{l})$ showed that apolipoprotein $\mathrm{C}$-IIII plasma concentrations wère positively correlated with plasma triglycerides ( $\mathrm{r}=$ $0.93)$ and total plasma cholesterol $(r=0.83)$.

\section{Distribution of apolipoprotein C-III among the lipoprotein fractions}

The apolipoprotein C-III profile was investigated in 3 normal and 3 severe Fredrickson type V subjects

Tab. 2. Concentrations of apolipoprotein C-III (mean \pm SD) in plasma from normal and hyperlipoproteinaemic subjects.

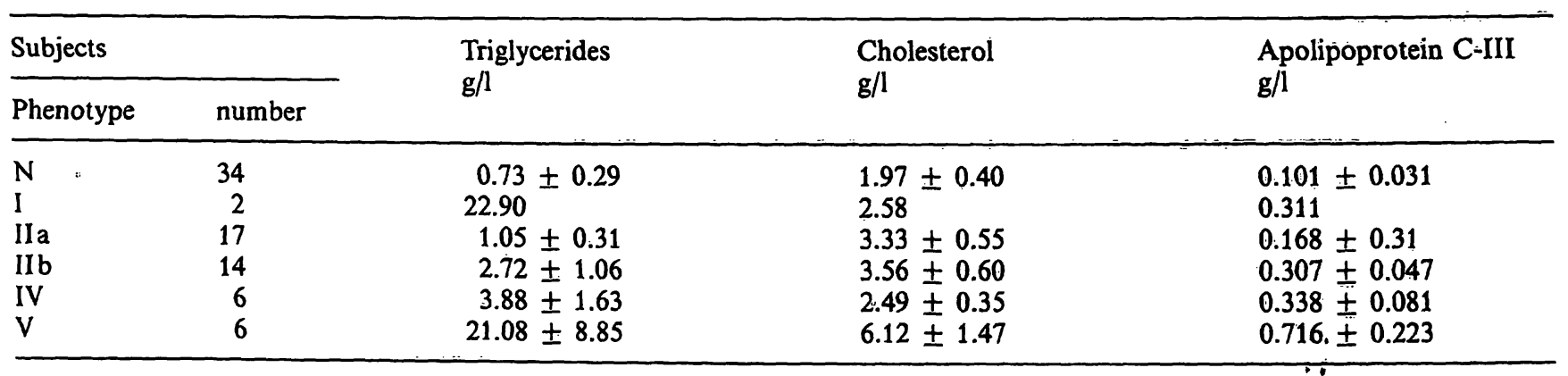


as described under methods. In the normolipaemic subjects apolipoprotein C-III was distributed as follows: $15.4 \pm 0.8 \%$ (mean $\pm S D$ ) in the Very Low Density Lipoproteins, $11.1 \pm 0.6 \%$ in Low Density Lipoproteins and $73.5 \pm 2.9 \%$ in High Density Lipoproteins. In the three Fredrickson type $\mathrm{V}$ patients $86.8 \pm 4.9 \%$ of the apolipoprotein C-III was found in the triglyceride-rich lipoproteins (i.e. chylomicra and Very Low Density Lipoproteins) while High Density Lipoproteins cholesterol contained only 5.6 $\pm 1.7 \%$ apolipoprotein C-III (cf. fig. 4 ).

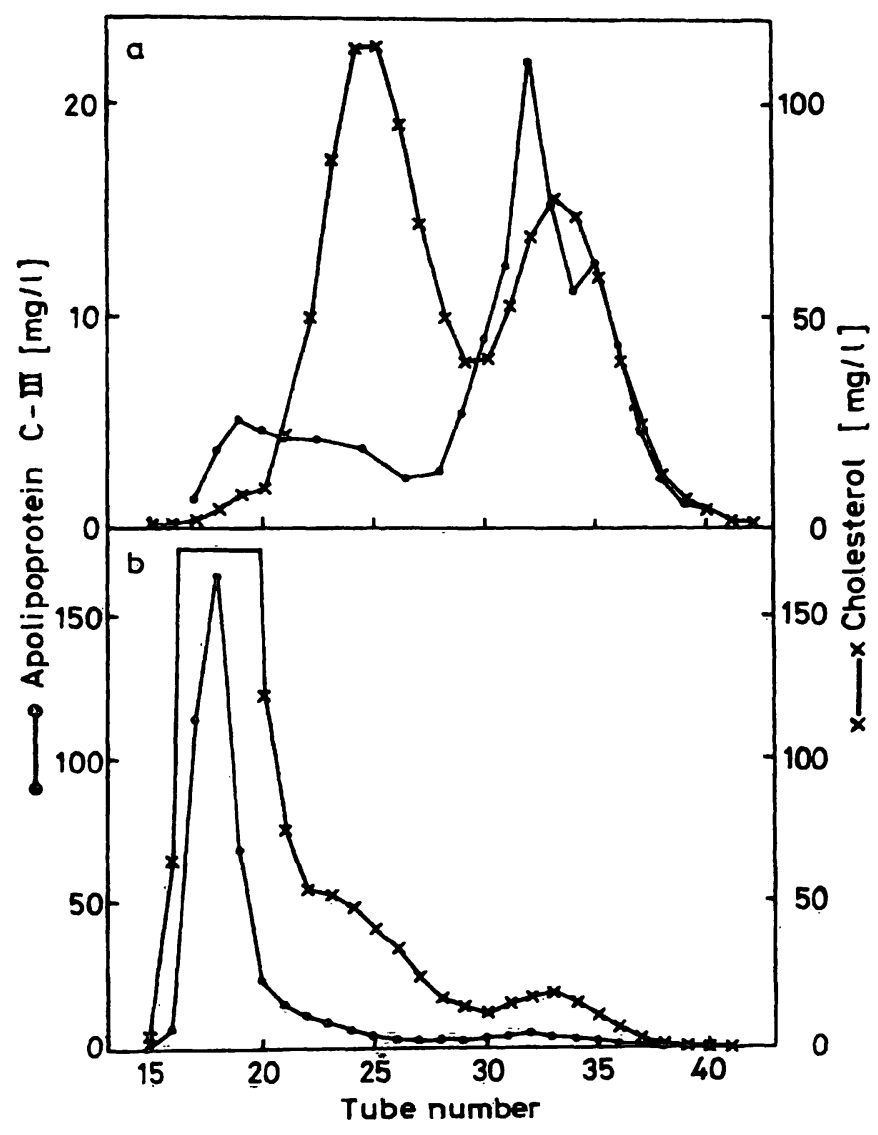

Fig. 4. Apolipoprotein C-III profile in a normolipaemic subject (a) and a patient with a Fredrickson type V hyperlipoproteinaemia (b). Fresh plasma $(1 \mathrm{ml})$ was separated on a Sepharose 6B column and apolipoprotein C-III (3) and cholesteról $(x)$ were measured in all fractions.

\section{Discussion}

Several immunological assays have been described for the measurement of human apolipoprotein C-III $(9-13)$ each of which has its own characteristics and limitations. For the electro-immunodiffusion assay (EID) the selection of a primary standard with the same migration properties as the unknown sample is critical. The major limitation of laser nephelometric assays is the sample turbidity. This is caused by the presence of triglyceride-rich lipoproteins, and necessitates sample delipidation prior to the assay (13). Radioimmunoassay is the most sensitive technique: down to $0.8 \mathrm{ng}$ apolipoprotein C-III (10). However, it suffers from various major drawbacks, including expensive counting equipment, unstable reagents and biohazards, associated with the handling of radioisotopes. These disadvantages can easily be circumvented by replacing the isotope label by an enzyme.

For this purpose a non-competitive enzyme linked immunosorbent assay was developed for the measurement of apolipoprotein C-III. The sandwich type assay was selected, as both coater and conjugate can be prepared from immunoglobulins with a high stability i. e.: the anti-apolipoprotein C-III-peroxidase conjugate was stable for at least 6 months, without loss of activity.

Standard curves, constructed either with plasma as a secondary standard or with lipoprotein fractions, paralleled the calibration curves, constructed with purified apolipoprotein C-III, which served as the primary standard. In contrast with the electroimmunoassay described by Curry et al. (11), the apolipoprotein C-III immunoreactivity was not enhanced by delipidation. Therefore, the ELISA assay does not detect any difference in the exposure of the apolipoprotein C-III epitopes, on the free or on the lipid-bound protein.

Compared with previously described techniques (CV: $6-13 \%)$, the use of affinity purified antibodies yielded a high assay sensitivity $(0.3 \mathrm{ng}$ apolipoprotein $\mathrm{C}$-III) and standard curves with a steep slope, together with a high assay precision (CV: $4 \%$ ).

The ELISA assay was evaluated by comparison with an immunonephelometric assay for apolipoprotein C-III, yielding a correlation coefficient of 0.982 ( $n=$ 79). Plasma apolipoprotein $\mathrm{C}$-III and triglyceride concentrations were well correlated $(r=0.93, n=76)$ as shown by a 3-fold increase of apolipoprotein C-III levels in patients with hypertriglyceridaemia (Fredrickson types I, II b and IV), and by a 5 to 10fold increase in patients with a Fredrickson type V hyperlipoproteinaemia as compared to normolipidaemic subjects.

Apolipoprotein C-III, which plays an important role in triglyceride catabolism, is distributed among triglyceride-rich lipoproteins and HDL. This distribution can easily be influenced by both 
endogeneous and exogeneous factors (32). Due to its sensitivity and precision this ELISA assay is especially suited to the study of apolipoprotein C-III profiles after plasma lipoprotein separation by either column chromatography or gradient ultracentrifugation.

This was demonstrated on normolipaemic and hypertriglyceridaemic plasma samples separated on a Sepharose 6B column. In agreement with previous reports $(9,11-13)$, the hypertriglyceridaemic state is attented by a higher amount of apolipoprotein $\mathrm{C}$-III in the triglyceride-rich lipoprotein fractions, suggesting that the apolipoprotein C-III profile could become a useful marker of triglyceride metabolism.

The characterization of the apolipoprotein C-III content and distribution in plasma should provide a better insight in to the function of this apolipoprotein in lipoprotein metabolism.

\section{Acknowledgement}

J. Bury was the recipient of an I.W.O.N.L. fellowship.

\section{References}

1. Albers, J. J. (1982) In: XI International Congress of Clinical Chemistry (Kaiser, E., Gabl, F., Müller, M. M. \& Bayer, M., eds.) pp. 221-228, Walter de Gruyter \& Co., Berlin.

2. De Backer, G., Rosseneu, M. \& De Slijpere, J.P. (1982) Atherosclerosis 42, 197-203.

3. Brown, W. V. \& Baginsky, M. L. (1972) Biochem. Biophys. Res. Commun! 46, 375-381.

4. Krauss, R.M., Herbert, P.N., Levy, R.I. \& Fredrickson, D. S. (1973) Circ. Res. 33, 403-411.

5. Shelbourne, F., Hanks, J., Meyers, W. \& Quarfordt, S. (1980) J. Clin. Invest. 65, 652-658.

6. Windler, E., Chao, Y. \& Havel, R. J. (1980) J. Biol. Chem. $255,8303-8307$.

7. Steinberg, K. K., Cooper, G. R., Graiser, G. R. \& Rosseneu, M. (1983) Clin. Chem. 29, 415-426.

8. Rosseneu, M., Vercaemst, R. Steinberg, R. K. \& Cooper, G. R. (1983) Clin. Chem. 29, 427-433.

9. Schonfeld, G., George, P. K., Miller, J., Reilly, P. \& Witztum, J. (1979) Metabolism 28, 1001-1010.

10. Kashyap, M.L., Srivastava, L.S., Hynd, B.A., Gartside, P. S. \& Perisotti, G. (1981) J. Lipid Res. 22, 800-810.

11. Curry, M.D., McConathy, W.J., Fesmire, J.D. \& Alaupovic, P. (1980) Biochim. Biophys. Acta 617, 503-513.

12. Holmquist, L. (1980) J. Immunol. Meth. 34, 243-251.

13. Bury, J., De Keersgieter, W. \& Rosseneu, M. (1985) Clin. Chim. Acta in press.

14. Davis, B. J. (1964) Ann. N. Y. Acad Sci. 121, 404-427.

15. Weber, K. \& Osborn, M. (1969) J. Biol. Chem. 244, 4406-4412.

16. Brewer, B. H., Shulman, R., Herbert, P., Ronan, R. \& Wehrly, K. (1974) J. Biol. Chem. 249, 4975-4984.

17. Blaton, V., Vercaemst, R., Rosseneu, M., Mortelmans, J., Jackson, R. L., Gotto, A. M.Jr. \& Peeters H. (1977) Biochemistry 16, 2157-2163.

18. Rosseneu, M., Vinaimont, N., Musliner, T., Bernier, D., Herbert, P. \& Belpaire, F. (1984) Clin. Chem. 30, 234-237.
19. Cardin, A. D., Witt, K. R., Barnhart, C. L. \& Jackson, R. L. (1982) Biochemistry 21, 4503 - 4511.

20. Pfaffinger, D., Edelstein, C. \& Scanu, A. M. (1983) J. Lipid Res. $24,796-800$.

21. Vercaemst, R., Bury, J. \& Rosseneu M. (1984) J. Lipid Res. $25,867$.

22. Rosseneu, M., Vercaemst, Vinaimont, N., Van Tornhout, P., Henderson, L. \& Herbert, P. (1981) Clin. Chem. 27, $856-859$.

23. Rosseneu, M., Vinaimont, N., Vercaemst, R., De Keersgieter, W. \& Belpaire, F. (1981) Anal. Biochem. 116, 204-210.

24. Affinity Chromatography (1975) Principles and Methods p. 15. Pharmacia Co. Publ. Uppsala Sweden.

25. Nakane, P. K. (1974) J. Histochem. Cytochem. 22, 1084-1091.

26. Voller, A., Bidwell, D. \& Bartlett, A. (1979) In: The enzyme linked immunosorbent assay. Dynatech Publ. Guernsey, U.K.

27. Samaké, H., Rajkowski, K. \& Cittanova, N. (1983) Clin. Chim. Acta 130, 129-135.

28. Kricka, L, Carter, T., Burt, S., Kennedy J., Holder R., Halliday, M., Telford, M. \& Wisdom G. (1980) Clin. Chem. 26, $741-744$.

29. Johnstone, A. \& Thorpe, R. (1982) Immunoassays. In: Immunochemistry in practice pp. $233-255$. Blackwell Scientific Publ. Oxford London Edinburgh Boston Melbourne.

30. Rosseneu, M., Van Biervliet, J. P., Bury, J. \& Vinaimont N. (1983) Ped. Res 17, 788-794.

31. Cham, B.E. \& Knowles, B.R. (1976) J. Lipid Res. 17, 176-181.

32. Kashyap, M. L., Barnhart, R. L.,.Srivastava, L. S., Perisotti, G., Aller, C., Hugg, E., Glueck, C.J. \& Jackson, R. L. (1983) Am. J. Clin. Nutr. 37, 233-243.

J. Bury

Department of Clinical Chemistry

A. Z. St-Jan

Ruddershovelaan 10

B-8000 Brugge 